\title{
Early clinical pathologists: Edward Jenner (1749-1823)
}

\author{
S Lakhani
}

\author{
"I've dispatched, my dear madam, this \\ scrap of a letter \\ To say that the patient is very much better \\ A regular Doctor no longer she lacks, \\ And therefore I've sent her a couple of \\ Quacks."
}

Edward fenner

The name of Edward Jenner is well known all around the world, for his contribution to immunisation rather than poetry. I thought it might be fair to begin with his less well known talent. During his life, he was the subject of considerable ridicule and malicious gossip, especially with regard to his work on immunisation, and he was often misquoted and misrepresented. As I have no desire to join the list of people guilty of such crimes I would like to clarify immediately that in the above verse, which he wrote to a lady enquiring after a patient, the "Quacks" refers to ducks (What else?).

Edward Jenner was born 17 May, 1749, at the vicarage, Berkeley, in Gloucestershire. He was the third son of Reverend Stephen Jenner, rector of Rockhampton and vicar of Berkeley. His two brothers, Stephen and Henry, had followed in their father's footsteps, and had read divinity at Oxford. Stephen, in particular, was very special to Edward, for it was he who had looked after him after their parents died when Edward was only 5 years old.

Edward started school at the age of 8, first at Wooton-under-Edge, and then at Cirencester Grammar School. He showed an early interest in natural history and by the age of 9 , had quite a collection of dormice nests and fossils. When he was 12 , he was sent to train as a country surgeon and became apprenticed to $\mathrm{Mr}$ Ludlow, a surgeon in Sodbury, near Bristol. It was here that Jenner acquired his initial training in surgery and pharmacy. In 1770, when Jenner was 21, Mr Ludlow decided to send him to London to finish his surgical training. It was in London that Jenner found a teacher and friend who was to influence profoundly the rest of his life's work. That man was John Hunter. Hunter was nearly 20 years his senior, yet despite the age difference, a deep bond of respect and friendship was forged between the two men. Under the guidance of his hero, Jenner extended his interests in surgery and natural history.

In 1771 Captain Cook returned from his voyages with a vast collection of natural history items and Jenner was given the task of cataloguing these. $\mathrm{He}$ did it so well that he was offered the post of naturalist on the ship for the next trip due to sail in 1772 . Hunter himself approved of this, both because of Jenner's obvious talents and the opportunity it afforded him to build on his personal collection. Jenner, however, declined the offer. His greatest desire was to return to his country practice in Gloucestershire, preferring the peace of the countryside to the fame and fortune guaranteed by the voyage. In Jenner's own words: "... What is its reward? At best a name. Praise-when the ear has grown too dull to hear. Gold-where the senses it should please are dead. Wreaths-where the hair they cover has grown grey. Fame-when the heart it should have thrilled is numb."

Jenner returned to Berkeley in 1773 to start his practice as a country surgeon, and by all accounts, he was a very friendly and popular member of the community. $\mathrm{He}$ had an unhappy love affair, and the much quoted letter from John Hunter, shows the closeness of the two men as well as their liaison in research into natural history:

"Dear Jenner,--I own that I was at a loss to account for your silence, and I was sorry at the cause . . . I can easily conceive how you must feel, for you have two passions to cope with, viz. that of being disappointed in love; and that of being defeated; but both will wear out, perhaps the first the soonest ... I want you to get a hedgehog, in the beginning of winter, and weigh him; put him in your garden, and let him have leaves, hay and straw to cover himself with, which he will do; then weigh him in spring and see what he has lost." (25th Sept 1778) ${ }^{1}$

Jenner did indeed recover, and in 1788 married Catherine Kingscote. They had two sons and one daughter. Jenner had some difficult times over the next decade. In 1789 his nephew George, who had been his assistant, left to work in Newfoundland with a medical missionary. This was followed by the death of John Hunter in 1793. In 1795, Jenner and his family were involved in an epidemic of typhus. Jenner himself only just survived; sadly, his brother Henry died of the disease. Despite these setbacks, Jenner managed to continue with his work in medicine and natural history.

His interests ranged from migration of birds to hibernation, but for me, Jenner's name is associated with two things: cuckoos and cows. It was John Hunter who was responsible for awakening Jenner's interest in cuckoos. He had asked Jenner to send him a "true and particular account of the cuckoo, as far as possible under your own eye". As most people will be aware, cuckoos arrive mid-April and the males sing from dawn till dusk. The female mates with several males, builds no nests, and within 
a month or so, begins to lay eggs in the nests of other birds. There are two things that I find particularly intriguing: despite the difference in size of the eggs, the cuckoo manages to lay eggs the same colour as the others in the nest and each year on return, the offspring manage to haunt the same type of bird that their mother did before. One of Jenner's most remarkable observations was that the newly born cuckoo was capable of turning out its companions from the nest.

"The mode of accomplishing this was very curious. The little animal with the assistance of its rump and wings, contrived to get the bird (the young hedge-sparrow) upon its back, and making a lodgement for the burden by elevating its elbows, clambered backward with it up the side of the nest till it reached the top, where resting for a moment, it threw off its load with a jerk, and quite disengaged it from the nest."2

Jenner sent his observations to the Royal Society which rejected them. Charles Waterton summed up the feeling in his essays: "No bird in the creation could perform such an astonishing feat under such embarrassing circumstances ... I I would much rather believe the story of baby Hercules throttling snakes."1 We now know that Jenner's observations were correct. They have been verified many times and the remarkable achievement of the young cuckoo was first photographed in $1929 .^{3}$

During Jenner's time, smallpox was a terrifying disease, not only because of the high mortality associated with it, but because it left the survivors with horribly scarred faces, and deaf and blind. The disease had been around for centuries at that time. Even before Jenner, it had been noticed that an attack of smallpox protected against further disease. It had been observed that the epidemics were of varying severity and that it was better to contract smallpox when a milder form occurred as this resulted in lifelong protection. This knowledge was widespread: in India children were wrapped in clothing from patients with smallpox; in China scabs from smallpox patients were ground and the powder was blown into the nostrils. In Turkey female slaves were injected under the skin with dried preparations of pus from smallpox patients. ${ }^{4}$ Inoculated slaves fetched a high price while pockmarked slaves were worth nothing.

Lady Mary Wortley Montagu, who was the wife of the British ambassador in Constantinople, was aware of these techniques and she took the risk of having her own children inoculated. When she returned to England in 1718, she tried to convince her friend, the Prince of Wales that he should do the same. He was worried about experimenting on the royal children, but when six orphan children were successfully immunised against smallpox, he consented.

Jenner, while a medical apprentice at Sodbury, had overheard a young woman say, "I cannot take smallpox, for I have had cowpox". Later while in London, he mentioned this to Hunter and to his colleagues at medical societies, but nobody considered his evidence seriously. The idea of using the cowpox virus to induce immunity to smallpox thrilled Jenner, and in 1796, he got the opportunity to do his final experiment. He came across a milkmaid, Sarah Nelmes, who had developed cowpox from milking a cow.

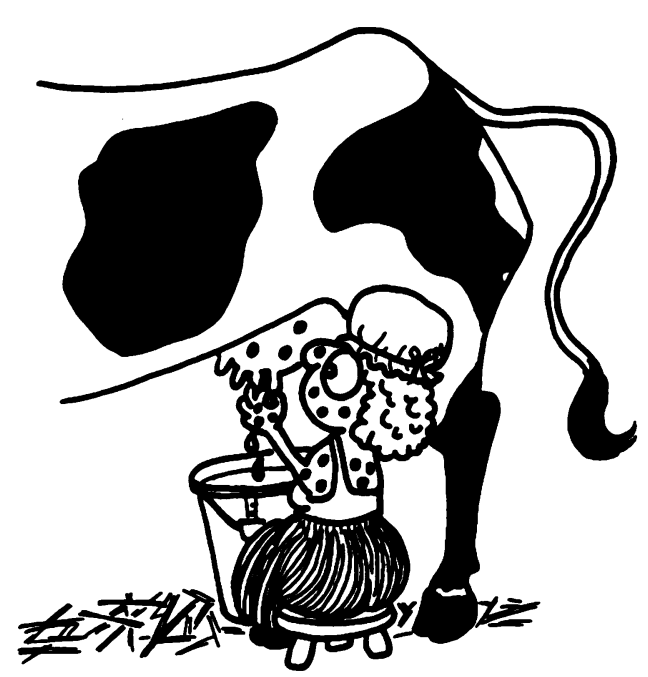

(Courtesy of Dr C Finlayson, St George's Hospital Medical School).

Jenner inoculated an 8 year old boy called James Phipps with cowpox lymph removed from one of the vesicles. The boy's illness took a predictable course and he recovered. On 1 July, he inoculated him with smallpox virus. No reaction occurred, either on this occasion or on the subsequent occasion a few months later. In 1798, Jenner published his work entitled An Inquiry into the Causes and Effects of the Variolae vaccinae. $A$ disease discovered in the Western Counties of England. For Jenner, it was a turning point in his life. He could see a means of saving large numbers of people from a dreadful disease, but to achieve it, he had to give up the lifestyle he had chosen and become a missionary of vaccination. It also meant that, for a time, he had to move back to London. He did indeed pursue his mission with great vigour and he attended many meetings and conferences to promote his findings. $\mathrm{He}$ also suffered many set backs as the wild rush for immunisation resulted in sloppy practices with disastrous results. However, the stage was set for a revolution and the progress continued relentlessly.

Having spent his time and personal fortune in the promotion of vaccination, it was decided that a claim for a grant should be put to the House of Commons. After much debate, a sum of $£ 10000$ was eventually agreed. Jenner received the money a year later, minus $£ 1000$ in tax. His fame and popularity, together with the vote of parliament to grant him the money resulted in considerable antagonism and hostility from some of his colleagues. At the forefront were Dr Pearson, a physician at St George's Hospital, who called Jenner's work "no discovery" but a "rascally ignorant business," and Dr Moseley, who stated his fears 
that immunisation with cowpox vaccine would result in the acquisition of animal characteristics. $^{3}$

This political and personal rivalry took its toll on Jenner and he eventually returned to Berkeley and resumed his practice. Mrs Jenner died in 1815; Jenner himself had his first stroke in 1820 , and three years later, sustained a second from which he died, on 25 January 1823. I find the historical accounts of Edward Jenner simultaneously uplifting and demoralising. Uplifting because they tell of a major revolution in our understanding of and care for the patient, and demoralising because they remind me that doctors have a long way to go.
"Nor do we believe that the virulence of political animosity, or personal rivalry, or revenge, ever gave rise among the lowest and most prostituted scribblers to so much coarseness, illiberality, violence, and absurdity as is here exhibited by gentlemen of sense and education, discussing a point of professional science with a view to the good of mankind."

Edinburgh Review ix. 63.

1 Drewitt FD. The life of Edward fenner. London: Longmans, Green and Co. 1931

2 Fisk D. Dr fenner of Berkeley. London: Heinemann, 1959. Harding Rains AJ. Edward fenner $\mathcal{E}$ vaccination. London: Priory Press Ltd, 1974.

4 Segerist HE. Great doctors. A biographical history of medicine. London: George Allen \& Unwin Ltd, 1935. 